University of Nebraska - Lincoln

DigitalCommons@University of Nebraska - Lincoln

Agronomy \& Horticulture -- Faculty Publications

Agronomy and Horticulture Department

$5-1990$

\title{
Registration of NP31 and NP32 Two Populations of Sudangrass Selected for Low Dhurrin Content
}

Francis A. Haskins

University of Nebraska-Lincoln, fhaskins@neb.rr.com

Herman J. Gorz

United States Department of Agriculture

K. P. Vogel

United States Department of Agriculture, kvogel1@unl.edu

Follow this and additional works at: https://digitalcommons.unl.edu/agronomyfacpub

Part of the Plant Sciences Commons

Haskins, Francis A.; Gorz, Herman J.; and Vogel, K. P., "Registration of NP31 and NP32 Two Populations of Sudangrass Selected for Low Dhurrin Content" (1990). Agronomy \& Horticulture -- Faculty Publications.

234.

https://digitalcommons.unl.edu/agronomyfacpub/234

This Article is brought to you for free and open access by the Agronomy and Horticulture Department at DigitalCommons@University of Nebraska - Lincoln. It has been accepted for inclusion in Agronomy \& Horticulture -Faculty Publications by an authorized administrator of DigitalCommons@University of Nebraska - Lincoln. 
REGISTRATION OF NP31 AND NP32, TWO POPULATIONS OF SUDANGRASS SELECTED FOR LOW DHURRIN CONTENT

NP31 AND NP32 SUDANGRASS [Sorghum bicolor (L.) Moench] [formerly S. sudanense (Piper) Staph] (Reg. no. 
GP-239 and GP-240; PI 535775 and PI 535776), two populations developed cooperatively by the USDA-ARS and the Nebraska Agricultural Research Division, were released in April 1989. These populations are potential sources of lowdhurrin germplasm for public and private sudangrass breeding programs. NP31 also contains the $m s_{3}$ gene for genetic male sterility and NP32 may be a source of sudangrass Blines.

NP31 was formed by compositing three experimental populations with similar germplasm that differed primarily in midrib and plant color. Each of the three populations was derived from the same germplasm sources that gave rise to NP22 (2) with one being restricted to plants with white midribs and tan plant color; another to plants with green midribs and tan plant color; and the third population, with mostly white midribs and purple plant color, represented four additional cycles of recurrent selection for lower dhurrin content in NP22 following the release of that population in 1982. Each of the two populations with tan plant color had six cycles of random mating. NP31 was not random-mated after the three components were composited; thus, the seed being released is a blend of equal quantities of the three component populations. Each of the three components contains the $m s_{3}$ gene for genetic male sterility.

Based on the mean of the three component populations, NP31 averages $233 \mathrm{~cm}$ in height at maturity. The population segregates for midrib and plant color. Glume color varies from black and mahogany to sienna, and caryopsis color is brown.

NP32 was derived from a low-dhurrin $F_{3}$ selection in a cross of a high-dhurrin sudangrass B-line obtained from commercial sources with a low-dhurrin selection from 'Piper'. Following additional selection of individual lowdhurrin seedlings in the $F_{4}, F_{5}$, and $F_{6}$ generations, NP32 was developed by selecting for lower dhurrin content in each of three cycles of phenotypic recurrent selection. The population averages $220 \mathrm{~cm}$ in height at maturity, has tan plant color, white midribs, straw-colored glumes, and light tan to brown caryopsis color. NP32 has not been evaluated with regard to the restoration of fertility when crossed to cytoplasmic male steriles but may be a source of sudangrass Blines because a B-line parent was involved in the initial cross.

The spectrophotometric assay for dhurrin (1) as measured by hydrocyanic acid potential of first leaves from 1-wk-old seedlings grown in the same test resulted in the following values for means and standard errors $\left(\mathrm{mg} \mathrm{kg}^{-1}\right.$ fresh weight, bulk of 10 seedlings per replication, three replications): NP31 fertile bulk-225 \pm 32 ; NP31 male-sterile bulk-216 \pm 11 ; NP32-131 \pm 10 ; NP25 fertile bulk $-181 \pm 11$; NP25 malesterile bulk-228 \pm 26 ; Piper-325 \pm 121 ; and 'Greenleaf'$567 \pm 32$

Seed will be maintained and distributed by the Department of Agronomy, University of Nebraska, Lincoln, NE 68583. Germplasm amounts will be provided without cost to each applicant upon written request while supplies last. Two different types of NP31 are available for distribution: (i) bulked seed harvested from genetic male-sterile plants (GP-239), and (ii) bulked seed harvested from fertile plants. The single lot of NP32 seed for distribution was open-pollinated in isolation. Recipients of the seed are asked to make appropriate recognition of the source of the germplasm if it is used in the development of a new germplasm, parental line, cultivar, or hybrid.

\section{F. A. Haskins, * H. J. Gorz, AND K. P. Vogel (3)}

\section{References and Notes}

1. Gorz, H.J., W.L. Haag, J.E. Specht, and F.A. Haskins. 1977. Assay of phydroxybenzaldehyde as a measure of hydrocyanic acid potential in sorghums. Crop Sci. 17:578-582.
2. Gorz, H.J., F.A. Haskins, S.D. Kindler, and A. Sotomayor-Rios. 1984 Registration of NP22 sudangrass germplasm. Crop Sci. 24:391.

3. H.J. Gorz (retired) and K.P. Vogel, USDA-ARS; and F.A. Haskins (retired), Dep. of Agronomy, University of Nebraska, Lincoln, NE 68583. Cooperative investigations of USDA-ARS and the Nebraska Agric. Res Division. Published as Journal Series Paper no. 8932, Nebraska Agric. Res. Division. Registration by CSSA. Accepted 31 Aug. 1989. *Corresponding author.

Published in Crop Sci. 30:759-760 (1990). 